\title{
Incidence, Severity, and Characterization of Phytophthora Foot Rot of Citrus in Texas and Implications for Disease Management
}

\author{
Shima Chaudhary, ${ }^{1,2,3}$ David A. Laughlin, ${ }^{1}$ Mamoudou Setamou, ${ }^{1}$ John V. da Graça, ${ }^{1}$ Madhurababu Kunta, \\ Olufemi J. Alabi, ${ }^{4}$ Kevin M. Crosby, ${ }^{3}$ Kevin L. Ong, ${ }^{5}$ and Veronica Ancona ${ }^{1, \dagger}$ \\ ${ }^{1}$ Citrus Center, Texas A\&M University-Kingsville, Weslaco, TX 78599, U.S.A. \\ ${ }^{2}$ Biology Department, South Texas College, McAllen, TX 78501, U.S.A. \\ ${ }^{3}$ Department of Horticultural Sciences, Texas A\&M University, College Station, TX 77843, U.S.A. \\ ${ }^{4}$ Department of Plant Pathology and Microbiology, Texas A\&M AgriLife Research \& Extension Center, \\ Weslaco, TX 78596, U.S.A. \\ ${ }^{5}$ Department of Plant Pathology and Microbiology, Texas A\&M University, College Station, TX 77843, U.S.A.
}

\begin{abstract}
Phytophthora-induced foot rot, also known as gummosis, is an important disease affecting citrus production worldwide. In Texas, the third-largest citrus-producing state in the United States, limited information is available on the etiology and epidemiology of foot rot in commercial orchards. This study comprises a survey of foot rot incidence and severity in Texas and the characterization of Phytophthora isolates associated with the disease. Surveys in 2015 and 2017 of 30 orchards in the Lower Rio Grande Valley (LRGV) region where commercial citrus production is concentrated in the state revealed that foot rot occurred in $97 \%$ of the orchards assessed. Overall, foot rot symptoms were observed on $33.7 \%$ of the trees evaluated and the disease severity index in the region was rated

the surveyed orchards and from five additional residential sites on the Texas Coastal Bend (TCB). Sporangia and chlamydospores from 34 representative LRGV isolates of $P$. nicotianae were larger than those of TCB isolates. In both LRGV and TCB, A1 and A2 mating types were present in the same location, albeit the A2 mating type was more prevalent. All isolates were sensitive to mefenoxam $(50 \%$ inhibition in the presence of mefenoxam $\left[\mathrm{EC}_{50}\right]<0.5 \mu \mathrm{g} / \mathrm{ml}$ ), except for one TCB isolate $\left(\mathrm{EC}_{50}=143.6 \mu \mathrm{g} / \mathrm{ml}\right)$. Our research indicates that treatment for Phytophthora foot rot in the region is necessary and, although mefenoxam is still useful, alternating chemistries for resistance management are required.
\end{abstract} at 14.2 and $16.5 \%$ in 2015 and 2017 , respectively. Lesions were mostly present on the scion, while the rootstock (sour orange) was not affected. Phytophthora nicotianae was the only Phytophthora sp. isolated from
Keywords: citrus foot rot, Lower Rio Grande Valley, mefenoxam, Phytophthora nicotianae
Phytophthora foot rot and root rot are important citrus diseases in all of the main citrus-producing regions in the world (Erwin and Ribeiro 1996). Under suitable conditions, Phytophthora spp. can infect the root system, causing root rot and the destruction of the feeder roots, which turn soft, with the cortex sloughing off from the stele, leading to poor water and nutrient uptake (Graham et al. 2014). Foot rot, also known as gummosis, is characterized by lesions that extend from the bud union to the major limbs of the scion and the production of amber-colored gum exudates in the branches (Graham and Feichtenberger 2015). On scions grafted to highly susceptible rootstocks such as sweet orange, Cleopatra mandarin, and rough lemon, lesions may extend around the base of the main trunk, causing partial or complete girdling and cambium damage. Affected trees show small chlorotic leaves, a thinning canopy, and twig dieback, leading to reduction of yield and fruit size (Graham and Feichtenberger 2015). Phytophthora brown rot of fruit causes the rind to become leathery and light brown in color. Infected fruit fall off the tree before harvest but some fruit may not show symptoms until during storage, causing major postharvest problems (Erwin and Ribeiro 1996).

${ }^{\dagger}$ Corresponding author: V. Ancona; veronica.ancona-contreras@tamuk.edu

Funding: TAMUK-Citrus Center Startup funds to V. Ancona and the Texas Citrus Producers Board.

*The $\boldsymbol{e}$-Xtra logo stands for "electronic extra" and indicates that four supplementary tables are published online.

The author(s) declare no conflict of interest.

Accepted for publication 11 March 2020.

(C) 2020 The American Phytopathological Society
The three main Phytophthora spp. that have been identified to cause foot rot and root rot in citrus include Phytophthora nicotianae Breda de Haan (syn. P. parasitica Dastur), P. citrophthora (R. E. Sm. \& E. H. Sm) Leonian, and P. palmivora (E. J. Butler) E. J. Butler (Graham and Menge 1999). In subtropical climates where elevated temperatures and high humidity are common, $P$. nicotianae is the most prevalent species, whereas $P$. citrophthora is mostly found in Mediterranean climates (Graham and Menge 1999; Timmer et al. 2000). In Florida, the most common species isolated from soils in disease-affected orchards are $P$. nicotianae and $P$. palmivora (Graham et al. 1998; Zitko and Timmer 1994; Zitko et al. 1991). In California, $P$. nicotianae and $P$. citrophthora have been the main Phytophthora spp. isolated from the citrus rhizosphere, with $P$. nicotianae being more abundant in summer than in cooler months (Dirac et al. 2003; Menge et al. 1988). A recent report indicated that $P$. citrophthora and $P$. syringae are mostly responsible for causing brown rot of citrus in California, with $P$. citrophthora occurring year-round, and $P$. syringae present only in the winter months (Hao et al. 2018). In Texas, earlier studies reported the presence of $P$. nicotianae in bark, soil, and fruit collected from commercial citrus orchards (Timmer 1973). More recently, PCR-based approaches have identified the presence of $P$. nicotianae (Kunta et al. 2007; RoyChowdhury et al. 2016) and P. citrophthora (RoyChowdhury et al. 2016), although the latter species has not been confirmed by culturing.

Commercial citrus production in Texas is located in Hidalgo, Cameron, and Willacy Counties, a region called the Lower Rio Grande Valley (LRGV; Fig. 1). Foot rot has been reported in most commercial orchards since the introduction of citrus to this region (Timmer 1972). Flood irrigation is the prevalent irrigation method for citrus production. Highly calcareous soils, soil salinity (800 to $900 \mathrm{mg} \mathrm{liter}^{-1}$ ), and poorly drained soils in the LRGV favor Phytophthora sp. establishment and continuous inoculum pressure (Blaker and MacDonald 1986; Timmer 1972; Wiedenfeld 2008). 
A recent assessment of Phytophthora spp. soil propagule counts in 61 citrus orchards across the LRGV indicated that $33 \%$ of orchards had populations exceeding $10 \mathrm{CFU} / \mathrm{cm}^{3}$ (RoyChowdhury et al. 2016), the treatment threshold for this pathogen (Graham and Menge 1999). However, the current incidence and severity of foot rot in Texas citrus orchards is largely unknown.

Control strategies against foot rot and root rot of citrus include the use of resistant rootstocks, fungicide treatments, and proper water management (Hao et al. 2019). Sour orange is the most common rootstock used for citrus production in the LRGV due to its moderate tolerance to high soil $\mathrm{pH}$ and root rot. However, foot rot can develop on aerial parts of the tree on susceptible scion cultivars independently of the rootstock (Furr and Carpenter 1961; Timmer 1972). Metalaxyl, mefenoxam, and fosetyl-Al are systemic fungicides that have been widely used for controlling Phytophthora diseases on citrus and they are effective in improving root growth and fruit yield (Sandler et al. 1989). However, due to their excessive use, resistant isolates of $P$. nicotianae have been reported in citrus nurseries and young orchards in Florida (Timmer et al. 1998). In California, there are reports of $P$. citrophthora isolates resistant to potassium phosphite fungicides (Förster et al. 2016). In Texas, citrus growers also utilize these chemistries for managing Phytophthora diseases but there is no information available on the sensitivity of Texas isolates to these fungicides.

Heterothallic species such as $P$. nicotianae require both mating types (A1 and A2) to produce sexual spores (Judelson and Blanco 2005). Oospores can act as resting spores due to their thick walls that protect spore viability (Judelson and Blanco 2005). In the LRGV, the presence of the two mating types of $P$. nicotianae has been reported (Timmer 1973). The possible occurrence of oospores in citrus orchards suggests that the population may have high genetic and phenotypic diversity, which may have implications in pathogen adaptation to changing environmental conditions such as development of fungicide resistance.

In order to develop more effective strategies to manage Phytophthora foot rot in the LRGV region, the goals of this study were to (i) conduct surveys to quantify the incidence and severity of foot rot in commercial citrus orchards in the LRGV, (ii) identify the Phytophthora spp. associated with citrus foot rot and gummosis in the LRGV, (iii) characterize the isolates for phenotypic diversity and pathogenicity, and (iv) evaluate their sensitivity to the commonly used fungicide mefenoxam.

\section{Materials and Methods}

Disease surveys. Surveys were conducted in commercial citrus orchards in the LRGV region (Hidalgo, Willacy, and Cameron Counties) from February to June 2015 and 2017. In all, 30 orchards were selected, reflecting the extent of citrus production in each county: 20 from Hidalgo, 8 from Cameron, and 2 from Willacy County. Citrus spp. included grapefruit (Citrus $\times$ paradisi Macf.; 23 orchards), sweet orange (Citrus sinensis (L.) Osbeck; five orchards), and tangerine (C. reticulata Blanco; two orchards), all grafted onto sour orange rootstock $(C$. aurantium $\mathrm{L}$.). Orchards ranged in size from 4 to 8 ha. Twenty randomly selected trees along a diagonal transect in each orchard were evaluated for foot rot incidence and severity. Incidence was determined as a percentage of symptomatic trees of total number of trees assessed. Disease severity was assessed based on a scale of 0 to 5 , where $0=$ lesion-free tree; $1=$ tree with $<10 \%$ of the main trunk covered with lesions, callus formation, and no vertical lesion extension to the branches; $2=$ tree with 11 to $35 \%$ of the main trunk covered with lesions, wound closed with some callus formation; $3=$ tree with $65 \%$ of the main trunk covered with lesions, lesions vertically extended to the branches; $4=$ tree with $90 \%$ of the main trunk covered with lesions, always associated with gummosis, lesions vertically extended to the branches; and $5=$ tree with $>90 \%$ of the trunk covered with lesions, showing extensive gummosis and extending to major branches. The disease rating scale was utilized to calculate the disease severity index (DI) per orchard using the formula DI $(\%)=\left[\sum(v f) /(N D)\right] \times 100($ McKinney 1923), where $v=$ foot rot severity score, $f=$ frequency of trees with a given rating, $N=$ total number of trees assessed in the orchard, and $D$ is the highest disease severity score. The location of lesions below or above the bud union and their presence on the tree branches versus the trunk were noted. Orchard age was also recorded. Orchards $\geq 20$ years of age were categorized as old and those $<20$ years old as young. To evaluate foot rot incidence and severity progression in floodirrigated orchards (the prevalent irrigation method in the LRGV), 20 of the 30 orchards studied in 2015 were evaluated again in 2017.

Isolation and quantification of Phytophthora propagules. A soil core $20 \mathrm{~cm}$ in depth was collected from the drip line of each of

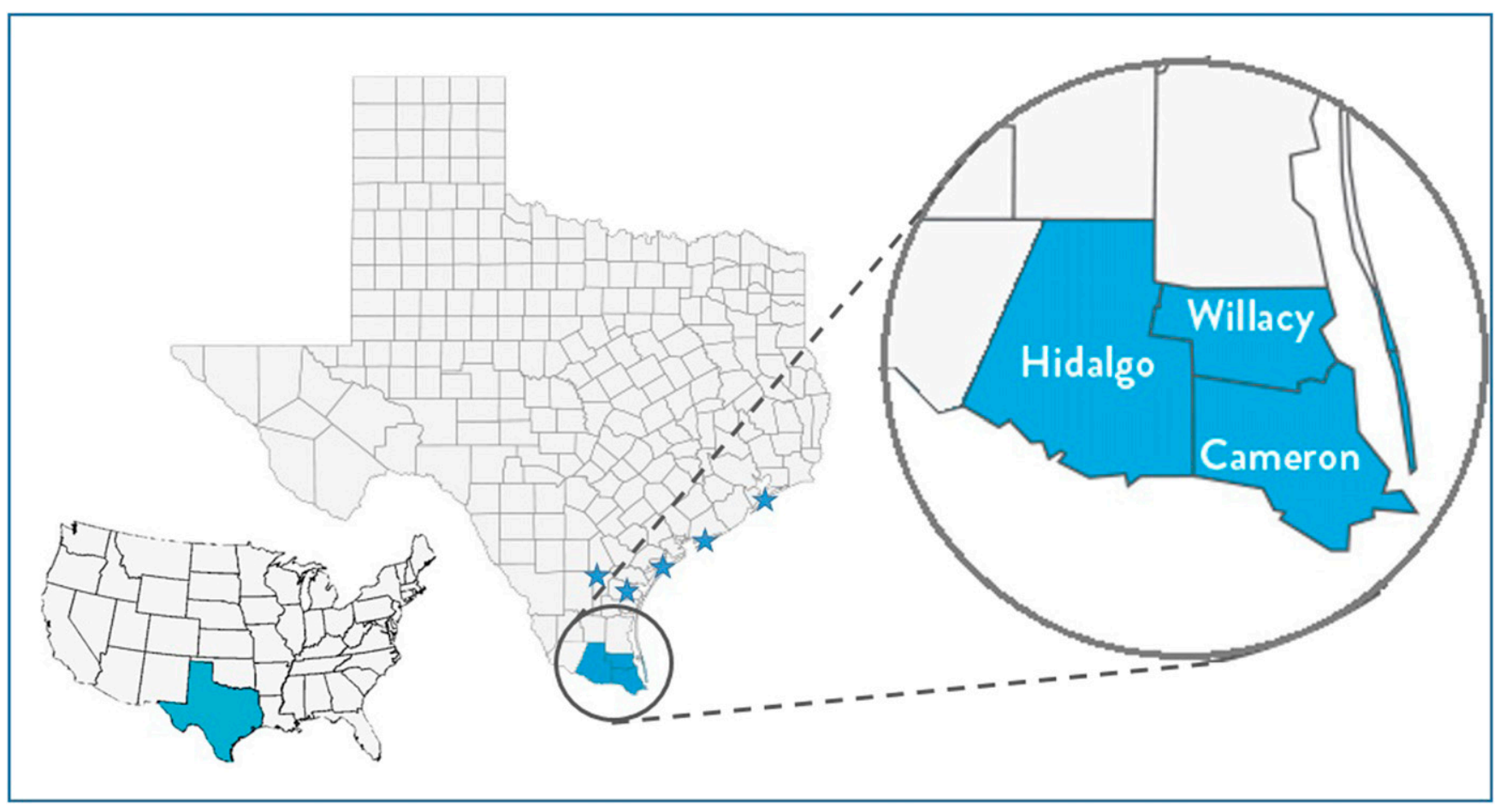

Fig. 1. Surveyed areas in the Texas Lower Rio Grande Valley and Texas Coastal Bend. 
the 20 evaluated trees per orchard. A composite sample of the orchard was generated by mixing $100 \mathrm{~cm}^{3}$ of each of the 20 cores. Soil cores from five residential trees along the Texas Coastal Bend (TCB) were collected from the four quadrants within the drip line in each tree and mixed thoroughly to make one composite sample per site. Phytophthora spp. propagules were quantified from each composite sample as described previously (Timmer et al. 1988). Briefly, $100 \mathrm{~cm}^{3}$ of soil was saturated in $100 \mathrm{ml}$ of sterile distilled water and allowed to drain for $48 \mathrm{~h}$. A $10 \%$ ( $\mathrm{vol} / \mathrm{vol}$ ) soil slurry was made by mixing $10 \mathrm{~cm}^{3}$ of drained soil in $90 \mathrm{ml}$ of sterile distilled water. The slurry $(1 \mathrm{ml})$ was plated onto each of five plates containing PARPH $(5 \mathrm{mg}$ of pimaricin, $250 \mathrm{mg}$ of ampicillin, $10 \mathrm{mg}$ of rifamycin, $50 \mathrm{mg}$ of pentachloronitrobenzene, and $50 \mathrm{mg}$ of hymexazol per liter)-corn meal agar (CMA; Hardy Diagnostics, Santa Maria, CA, U.S.A.). The plates were incubated in the dark for 5 days at $23 \pm 2{ }^{\circ} \mathrm{C}$, and distinctive Phytophthora colonies were quantified. Propagule counts were recorded as CFU per cubic centimeter of soil. Two to three Phytophthora colonies per location were isolated and subcultured to obtain single zoospore colonies as previously described (Erwin and Ribeiro 1996) to generate singlegenotype isolates for identification and characterization.

Phytophthora sp. isolation from roots. Fibrous roots from randomly selected soil samples were surface sterilized with $70 \%$ ethanol for $10 \mathrm{~s}$, immersed in $0.6 \%$ sodium hypochlorite solution for $1 \mathrm{~min}$, and rinsed with sterile water three to four times before plating onto PARPH-CMA. Plates were incubated in the dark for 5 days, and Phytophthora colonies were subcultured on $10 \%$ clarified V8 agar plates (CV8A) (Ferguson and Jeffers 1999). Single-zoospore colonies were obtained from all the Phytophthora isolates from roots, as previously described (Erwin and Ribeiro 1996).

Molecular identification. Phytophthora colonies growing in $10 \%$ clarified V8 (CV8) broth (100 ml of Campbell V8 vegetable juice, clarified by centrifugation at $8,000 \mathrm{rpm}$ for $10 \mathrm{~min}$, and $1 \mathrm{~g}$ of $\mathrm{CaCO}_{3}$ per liter of water) at $22^{\circ} \mathrm{C}$ for 7 days were used to isolate total DNA with the DNeasy Plant Mini Kit (Qiagen Inc., Valencia CA, U.S.A.) according to the manufacturer's instructions. The nuclear ribosomal DNA internal transcribed spacer (ITS) region, including the $5.8 \mathrm{~S}$ and the mitochondrial cytochrome c oxidase (cox) genes, was amplified using the primer pair ITS4 and ITS6 and FMPhy-8b and FMPhy-10b, respectively (Cooke et al. 2000; Martin et al. 2004; White et al. 1990). The PCR mixtures consisted of $1 \times$ PCR buffer, $2 \mathrm{mM} \mathrm{MgCl}_{2}$, $0.2 \mathrm{mM}$ dNTP mix, $0.2 \mu \mathrm{m}$ each forward and reverse primer, $1.25 \mathrm{U}$ of GoTaq DNA polymerase (Promega Corp., Madison, WI, U.S.A.), and nuclease-free water to make a 50- $\mu$ l total volume. Amplification was carried out in a MyCycler thermal cycler (Bio-Rad Laboratories Inc., Hercules, CA, U.S.A.), with an initial denaturation at $94^{\circ} \mathrm{C}$ for $3 \mathrm{~min}$, followed by 35 cycles at $94^{\circ} \mathrm{C}$ for $1 \mathrm{~min}, 55^{\circ} \mathrm{C}$ for $1 \mathrm{~min}$, and $72^{\circ} \mathrm{C}$ for $1 \mathrm{~min}$ for ITS primers; or $94^{\circ} \mathrm{C}$ for $2 \mathrm{~min}$, followed by 35 cycles at $94^{\circ} \mathrm{C}$ for $30 \mathrm{~s}, 50^{\circ} \mathrm{C}$ for $30 \mathrm{~s}$, and $72^{\circ} \mathrm{C}$ for $30 \mathrm{~s}$ for cox primers. PCR products were visualized by electrophoresis in a $1 \%$ agarose gel stained with ethidium bromide. The PCR products were purified using QIAquick PCR purification (Qiagen) and submitted to McLAB DNA Sequencing Services (San Francisco, CA, U.S.A.) for sequencing in both directions. The sequences were compared for similarities in the NCBI GenBank database using the BLASTn algorithm.

Cultural characterization of Phytophthora isolates. Morphological characterization was performed for selected isolates to represent most orchards. Sporangia formation was induced by incubating actively growing mycelium of a 7-day-old culture on 10\% CV8A under fluorescent light for $24 \mathrm{~h}$. Agar plugs were mounted on a slide, stained with 1 to 2 drops of $0.1 \%$ Lacto-Fuchsin $(0.1 \mathrm{~g}$ of acid fuchsin per $100 \mathrm{ml}$ of $85 \%$ lactic acid) and incubated overnight at $23 \pm 2{ }^{\circ} \mathrm{C}$. Sporangia were visualized using $\times 40$ magnification objective with a Leica DM750 microscope (Leica Microsystems, Wetzlar, Germany). The length and breadth of five sporangia per isolate were measured with the microscope image analysis software program (Leica application software; Leica Microsystems). Chlamydospores were observed in 10- to 15-day-old 10\% CV8A cultures. The diameters of five chlamydospores per isolate were measured as above. The mating type was identified by pairing isolates with known A1 and A2 tester isolates of $P$. capsici (provided by Dr. J. L. Hernandez, Centro de Biotecnologia Genomica, IPN, Reynosa, Mexico). Plugs (5 mm in diameter) from unknown and tester isolates were placed on opposite sides of $10 \%$ CV8A plates (Erwin and Ribeiro 1996). Plates were incubated at $23 \pm 2{ }^{\circ} \mathrm{C}$ in the dark for 10 days. The presence of oospores in the interaction zone was recorded and used to determine the mating type. Agar plugs with oospores were mounted on a microscope slide and stained with Lacto-Fuchsin to measure antheridium width, as well as oogonium and oospore diameters. Colony patterns were determined for 7-day-old colonies on potato dextrose agar (PDA) and CV8A and classified as slight chrysanthemum, slight stellate, slight rosaceous to diffuse, radiate, or chrysanthemum (Erwin and Ribeiro 1996).

Sensitivity to mefenoxam. Plugs $(5 \mathrm{~mm}$ in diameter) from actively growing 5-day-old Phytophthora spp. cultures were transferred onto 10\% CV8A amended with mefenoxam (Ridomil Gold SL EC; Syngenta Crop Protection, Greensboro, NC, U.S.A.) active ingredient at $0,0.1,1$, or $10 \mu \mathrm{g} / \mathrm{ml}$. All isolates were plated in triplicate and incubated in the dark for 5 days at $23 \pm 2{ }^{\circ} \mathrm{C}$. Radial growth was measured and averaged, and percent growth was calculated by dividing the radial growth on amended media by growth on nonamended media (Timmer et al. 1998). Two independent experiments were performed, and data were pooled for analysis after confirming homogeneity of variances using Bartlett's test. Percent growth inhibition was determined and converted to probits (MSexcel formula NORM.S.INV [probability]). Probit values were plotted against $\log _{10}$-transformed fungicide concentrations (Finney 1962). The regression equation was used to calculate 50 and $90 \%$ inhibition in the presence of mefenoxam $\left(\mathrm{EC}_{50}\right.$ and $\mathrm{EC}_{90}$, respectively) values. Isolates that grew with mefenoxam at $10 \mu \mathrm{g} / \mathrm{ml}$ were also tested at 100 and $1,000 \mu \mathrm{g} / \mathrm{ml}$.

Pathogenicity tests on citrus and alternative hosts. The pathogenicity of 20 selected isolates was tested on seedlings of sour orange (C. aurantium) and four noncitrus hosts, including tomato (Solanum lycopersicum), garden bean (Phaseolus vulgaris), summer squash (Cucurbita pepo), and Russell hybrid lupin (Lupinus polyphyllus). Zoospore inoculum was prepared by transferring 5-mm-diameter plugs from 5-day-old cultures into $15 \mathrm{ml}$ of a sterile soil solution (Jeffers 2006). After $24 \mathrm{~h}$ under fluorescent light, zoospore release was initiated by incubating at $4^{\circ} \mathrm{C}$ for $3 \mathrm{~h}$ and then in the dark for $30 \mathrm{~min}$ at $23 \pm 2{ }^{\circ} \mathrm{C}$. Roots of three 6-week-old plants grown under greenhouse conditions were immersed overnight in a zoospore suspension $\left(10^{4}\right.$ zoospores $\left./ \mathrm{ml}\right)$ of each tested isolate (Matheron and Matejka 1990). Control plants were inoculated in sterile distilled water. Seedlings were planted into sterile potting soil mix, maintained in the greenhouse, and watered daily to maintain high moisture conditions. Pathogenicity on sour orange seedlings was assessed on nine seedlings per isolate after 10 weeks. For each isolate, 30 root segments with visible lesions were plated onto PARPH-CMA. Plates were incubated in the dark for 4 to 5 days, and the percentage of root segments that resulted in Phytophthora colonies was calculated.

On alternative hosts, plant mortality was assessed after 3 days, and the experiment was terminated after 7 days. Seedling mortality and the presence of lesions on roots, stems, and leaves were recorded. The entire seedlings, including roots, stems, and leaves, were cut into segments, plated onto PARPH-CMA, and incubated in the dark for 4 to 5 days. Based on lesion size, percent plant part infected, and mortality, isolates were grouped into three categories: highly virulent (+++) on the host if all three seedlings died, the lesions covered more than $90 \%$ of the seedling, and Phytophthora sp. was isolated from all plated plant segments; moderately virulent (++), if two of the three seedlings died, lesions were present in 40 to $90 \%$ of the seedling, and all plated segments resulted in positive isolations; and low virulence (+), when only one of the three seedlings died, lesions were present in less than $40 \%$ of the seedling, and Phytophthora sp. was recovered from the plated plant segments. Isolates were considered nonpathogenic (negative) if they caused no mortality, no lesions were present, and no Phytophthora sp. grew from plated segments. 
Statistical analysis. Percent data were arcsine-transformed while propagule counts were $\log (x+1)$-transformed before analyses. Analysis of variance was used to evaluate the effect of tree age on disease incidence and severity in the orchards and the number of propagules. Data were analyzed with PROC GLM (SAS version 9.4 for Windows; SAS Institute, Cary, NC, U.S.A.) to test significance. Mean separations were made by the Student-Newman-Keuls multiple range test if $F$ values were significant $(P \leq 0.05)$.

\section{Results}

Foot rot incidence and severity. A 2015 survey in the three commercial citrus-growing counties in the LRGV of Texas revealed that foot rot was present in $97 \%$ of the 30 orchards surveyed. The incidence within orchards ranged from 5 to $90 \%$ and averaged 30 , 33.6, and $40 \%$ in Cameron $(n=8)$, Hidalgo $(n=20)$, and Willacy $(n=2)$ Counties, respectively. Overall, $33.7 \%$ of the 600 surveyed trees showed symptoms. Foot rot severity ranged from 1 to $57 \%$, with an average of $14.2 \%$ (Table 1 ).

Similar results were obtained in the 2017 survey. Mean foot rot incidences in orchards were 39 and $30.6 \%$ in Cameron and Hidalgo Counties, respectively. Although a slight increase in disease severity was observed in Cameron County, no notable change was observed in Hidalgo County (Table 1).

During the 2015 sampling, Phytophthora spp. propagules in orchard soils ranged from 0 to $118 \mathrm{CFU} / \mathrm{cm}^{3}$, and 23 of the 30 orchard soils had more than $10 \mathrm{CFU} / \mathrm{cm}^{3}$. Propagule counts in the 2017 assessment were significantly lower than in $2015(P=0.0094)$, with a mean of $9.1 \mathrm{CFU} / \mathrm{cm}^{3}$ and ranged from 0 to $46 \mathrm{CFU} / \mathrm{cm}^{3}$, and 8 of the 20 orchards had more than $10 \mathrm{CFU} / \mathrm{cm}^{3}$ (Table 2).

Older ( $>20$ years) grapefruit orchards had significantly higher foot rot incidence $(P=0.01)$ and disease severity $(P=0.02)$ compared with younger ( $<20$ years) orchards (Fig. 2). Phytophthora spp. soil propagule counts did not differ significantly between older and younger orchards. Symptoms of foot rot were present on 54\% (214 of 400) of tree branches compared with $34 \%$ (135 of 400) of tree trunks evaluated. There were no significant differences in the incidence of symptoms on trunk and branches between grapefruit and sweet orange trees $(P=0.9$ and 0.5 , respectively) (Table 3$)$. Only $7.25 \%$ (29 of 400) of the trees exhibited symptoms of foot rot on the sour orange rootstock.

Pathogen isolation and identification. During the 2015 survey, in total, 93 isolates were obtained from citrus roots and soil samples. In all, 81 isolates originated from 27 citrus orchards in the LRGV and 12 isolates from soils from residential citrus trees in the TCB. ITS sequence analysis of 89 isolates indicated 97 to $100 \%$ sequence identity to $P$. nicotianae, including all isolates collected from the TCB. Four isolates were identified as Pythium ultimum (PYE2 \& PYE3), P. nodosum (PyE1), and Phytopythium vexans (PyMi5) (Supplementary Table S1). Sequencing of the cox gene of 47 isolates confirmed the identity of isolates as Phytophthora nicotianae.

The assembled sequences were deposited into the GenBank database (accession numbers MH290367 to MH290397, MH290399 to MH290417, MH290419 to MH290446, and MH341608 to MH341622) (Supplementary Table S1). None of the sequenced isolates showed matches to $P$. citrophthora.
Morphological characterization. In all, $34(\mathrm{LRGV}=29$ and TCB $=5$ ) of the 89 Phytophthora isolates identified as $P$. nicotianae were selected for morphological characterization. Colony morphologies on $10 \%$ CV8A varied from chrysanthemum, radiate, stellate, to nondefined, whereas isolates grown on PDA exhibited mostly

Table 2. Phytophthora spp. soil propagules in surveyed orchards in 2015 and 2017 in the Lower Rio Grande Valley of Texas

\begin{tabular}{|c|c|c|c|c|}
\hline \multirow[b]{2}{*}{ County } & \multicolumn{2}{|r|}{2015} & \multicolumn{2}{|r|}{2017} \\
\hline & $N^{\mathbf{y}}$ & $\begin{array}{c}\text { Mean soil } \\
\text { propagules (range) }\end{array}$ & $N^{\mathbf{y}}$ & $\begin{array}{c}\text { Mean soil } \\
\text { propagules (range) }\end{array}$ \\
\hline Cameron & 8 & $21.1(0-62)$ & 5 & $5.8(0-13)$ \\
\hline Hidalgo & 20 & $31.5(0-118)$ & 15 & $12.9(0-46)$ \\
\hline Willacy & 2 & $9.5(4-15)$ & 0 & $\ldots$ \\
\hline Mean $^{\mathrm{z}}$ & $\ldots$ & $26.5 \pm 5.6$ & & $9.1 \pm 2.3$ \\
\hline$P$ value & $\ldots$ & 0.9 & & 0.6 \\
\hline
\end{tabular}

${ }^{\mathrm{y}} N=$ number of orchards.

${ }^{\mathrm{z}}$ Mean (range in parentheses) was significantly different between years 2015 and $2017(P=0.0094)$.

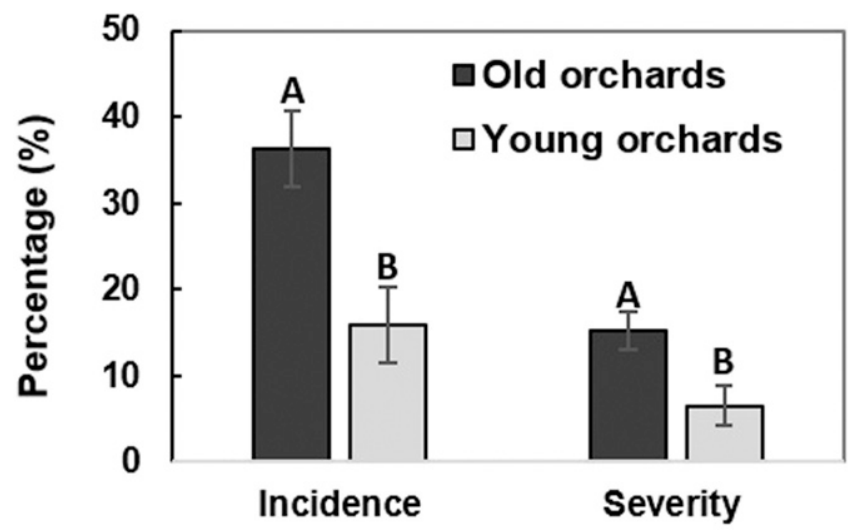

Fig. 2. Effect of orchard age on incidence and severity of Phytophthora foot rot of citrus. Orchards more than 20 years of age $(n=17)$ were compared with those less than 20 years old $(n=9)$. Error bars indicate standard error and different letters indicate significant differences $(P<0.05)$.

Table 3. Incidence of trees showing foot rot symptoms on branches, trunks and rootstocks ${ }^{y}$

\begin{tabular}{lccll}
\hline & & \multicolumn{3}{c}{ Infection (\%) of } \\
\cline { 3 - 5 } Scion & Orchards/trees $^{\mathbf{z}}$ & Branch & Trunk & Rootstock \\
\hline Grapefruit & $15 / 300$ & $56.3(10-90)$ & $33.3(10-70)$ & $7.6(0-30)$ \\
Sweet orange & $3 / 60$ & $51.6(30-85)$ & $30(25-35)$ & $5(0-15)$ \\
Tangerine & $2 / 40$ & $35(15-55)$ & $32.5(20-45)$ & $7.5(0-15)$ \\
$P$ value & $\ldots$ & 0.5 & 0.9 & 0.8 \\
\hline
\end{tabular}

y Incidence of branch infections was significantly higher than main trunk infections $(P=0.006)$ (range in parentheses).

$\mathrm{z}$ Number of orchards/trees assessed.

Table 1. Phytophthora foot rot incidence and severity in the citrus producing counties of the Lower Rio Grande Valley of Texas during spring of 2015 and 2017 survey

\begin{tabular}{|c|c|c|c|c|c|c|}
\hline \multirow[b]{2}{*}{ County } & \multicolumn{3}{|c|}{2015} & \multicolumn{3}{|c|}{2017} \\
\hline & $\overline{N^{x}}$ & Incidence $(\%)^{y}$ & $\overline{\text { Severity }(\%)^{\mathrm{z}}}$ & $\overline{N^{\mathrm{x}}}$ & Incidence $(\%)^{\mathrm{y}}$ & $\overline{\text { Severity }(\%)^{\mathrm{z}}}$ \\
\hline$\overline{\text { Cameron }}$ & 8 & $30.0(10-90)$ & $10.37(2-20)$ & 5 & $39.0(2-42)$ & $20.4(10-70)$ \\
\hline Hidalgo & 20 & $33.6(5-80)$ & $15.6(1-57)$ & 15 & $30.6(5-35)$ & $15.2(15-55)$ \\
\hline Willacy & 2 & $40.0(25-55)$ & $15.0(10-20)$ & 0 & $\ldots$ & $\ldots$ \\
\hline Means & $\ldots$ & $33.7 \pm 4.2$ & $14.2 \pm 2.2$ & $\ldots$ & $32.75 \pm 4.3$ & $16.5 \pm 3.0$ \\
\hline
\end{tabular}

$\mathrm{x}$ Number of orchards.

${ }^{y}$ Mean incidence was determined as percentage of trees expressing symptoms of the total number of trees assessed (range in parentheses).

${ }^{\mathrm{z}}$ Mean severity was calculated from the disease severity indexes from each orchard assessed per county (range in parentheses). 
stoloniferous growth (Supplementary Table S2). Vegetative hyphae were coralloid, showing hyphal swellings. More than one type of sporangium shape was noted for the same isolates. Ovoid, obpyriform, and spherical with single papilla were the more common shapes but spherical, bipapillate, and turbinate sporangia were also present. Both terminal and intercalary chlamydospores were observed (data not shown).

Sporangial size varied considerably among isolates; sporangium length and breadth ranged from $23.0 \pm 1.2$ to $47.5 \pm 2.5 \mu \mathrm{m}$ (mean $=47.7 \mu \mathrm{m}) \times 28.0 \pm 1.2$ to $65.7 \pm 3.3 \mu \mathrm{m}($ mean $=36 \mu \mathrm{m})$, respectively. Mean chlamydospore diameters for individual isolates ranged from $23.0 \pm 1.2$ to $50.7 \pm 1.9 \mu \mathrm{m}$, with a mean for all isolates of $36.1 \mu \mathrm{m}$ (Supplementary Table S2). Spore measurements conformed to the reported dimensions of $P$. nicotianae type species (Erwin and Ribeiro 1996). When LRGV and TCB isolates were compared, significant differences in chlamydospore diameter and sporangial length and width were detected (Table 4). Isolates obtained from sites along the TCB had significantly smaller sporangia lengths and breadths as well as chlamydospore diameters than those from the LRGV sites, although the sporangia length/breadth ratio was similar.

Mating type and characteristics of oospores. In total, 25 isolates were of mating type A2 and 9 isolates were of A1, because they only produced sexual spores when they were paired with A1 and A2 $P$. capsici tester isolates, respectively. Both mating types were present at the same site in 2 of the 20 LRGV orchards and 2 of the 5 TCB sites. Smooth and spherical amphigynous antheridia were formed in all pairings. The oogonial diameter ranged from $22.6 \pm 1$ to $26.8 \pm 0.4 \mu \mathrm{m}$, with an average of $24.9 \pm 0.16 \mu \mathrm{m}$. The antheridium diameter ranged from $8.0 \pm 1.2$ to $13.4 \pm 0.6 \mu \mathrm{m}$. Oospores were plerotic, ranging from $17.5 \pm 0.5$ to $22.8 \pm 0.4 \mu \mathrm{m}$ in diameter. Sizes of sexual reproductive structures of isolates from the LRGV and TCB were not significantly different $(P>0.05)$ (Table 4; Supplementary Table S3). None of the isolates produced sexual reproductive structures in single cultures, indicating that they were not self-fertile.

Mefenoxam sensitivity. P. nicotianae isolates from the LRGV exhibited different degrees of sensitivity to mefenoxam. Five isolates were highly sensitive, with $\mathrm{EC}_{50}$ values for mycelial growth of $0.001 \mu \mathrm{g} / \mathrm{ml}$, and 21 isolates had $\mathrm{EC}_{50}$ values between 0.01 and $0.2 \mu \mathrm{g} / \mathrm{ml}$. Three isolates had $\mathrm{EC}_{50}$ values between 0.2 and $0.5 \mu \mathrm{g} / \mathrm{ml}$ and were rated as moderately resistant because they had $\mathrm{EC}_{90}$ values between 3.0 and $10 \mu \mathrm{g} / \mathrm{ml}$ (Table 5; Supplementary Table S4).

Among the five isolates from the TCB area, one was highly sensitive, three were sensitive, and one was resistant. Growth of the resistant isolate $(\mathrm{PhCC} 63)$ at $100 \mu \mathrm{g} / \mathrm{ml}$ was similar as on nonamended agar. $\mathrm{EC}_{50}$ and $\mathrm{EC}_{90}$ values for this isolate were 143.6 and 2,615 $\mu \mathrm{g} / \mathrm{ml}$, respectively (Table 5; Supplementary Table S4).

Pathogenicity tests on citrus and noncitrus hosts. Pathogenicity of the isolates tested varied significantly, because not all of them were able to cause infection of every host. Sour orange seedlings inoculated with $15 P$. nicotianae isolates did not show visible signs of wilting or yellowing of leaves. However, 11 of the isolates caused some symptoms on the main root, while 4 were not pathogenic (Table 6).

The alternative host Lupinus was highly susceptible, and more than $88 \%$ of the plants were dead 4 days after inoculation. Lesions were present on all parts of the plant, and the pathogen was successfully isolated from the seedling when plated on selective media.
The numbers of $P$. nicotianae isolates pathogenic on squash and tomato seedlings were equal $(n=16)$; however, a higher mortality rate was observed on tomato because 12 isolates caused death of all inoculated seedlings, in contrast to only 4 isolates on squash. Only 7 of the isolates tested were able to colonize bean. They were recovered from stems and roots, although no visible lesions were observed. Only one isolate (PhLF25) was pathogenic on all hosts, whereas one isolate $(\mathrm{PhE} 32)$ did not cause disease on any of the four noncitrus hosts and only caused root lesions on sour orange (Table 6).

\section{Discussion}

This study is the first comprehensive report on the incidence and severity of Phytophthora foot rot of citrus in the LRGV of Texas. Our work demonstrated that foot rot is widespread in the main citrus-growing region of Texas, occurring in all commercial citrus orchards evaluated at various incidence levels. Although our survey indicated a mean severity index of 16.5, this may be underestimating the foot rot severity in the region because dead trees were not considered, as the cause of tree mortality was not known. The results from this study warrant the investigation of the economic impact of Phytophthora foot rot from tree death and decline in productivity.

Another important finding from this work is that lesions were mostly present on the scion and not on the rootstock. Although sour orange is considered a tolerant rootstock, it is surprising that, with flood irrigation, clay soils, and poor drainage, the percentage of foot rot on the rootstock was very low in surveyed orchards; mostly because during flood irrigation the bud union can be covered in orchards where trees are budded below $30 \mathrm{~cm}$. The higher percentage of trees with lesions in branches and limbs compared with the rootstock is similar to what has been observed in Spanish orchards, with $92 \%$ of lesions on the scion (Alvarez et al. 2008). Infection of scions could have occurred when $P$. nicotianae propagules were splashed onto wounded branches and trunks, especially those located close to the ground (Graham and Menge 1999). Hedging and topping citrus for tree size management create wounds that could serve as entry points for Phytophthora spp. inoculum. If equipment becomes contaminated, it could spread the pathogen not just from tree to tree but also among orchards if not decontaminated properly. High incidence of foot rot and gummosis has been reported from other citrusgrowing regions of the world such as Kenya, where noncertified planting material is used and favorable conditions for disease development are present (Mounde et al. 2009). In Texas, the mandatory use of potted citrus trees from certified nurseries did not come into effect until 2013 (Da Graça and Van Ness 2019). Future studies will

Table 5. Mefenoxam sensitivity of Phytophthora nicotianae isolates from citrus orchards in the Lower Rio Grande Valley (LRGV) and from the Texas Coastal Bend (TCB)

\begin{tabular}{lcc}
\hline Sensitivity rating & Number of isolates (LRGV/TCB) & EC $_{\mathbf{5 0}}$ value $^{\mathbf{z}}$ \\
\hline Highly sensitive & $5 / 1$ & $<0.001 \mu \mathrm{g} / \mathrm{ml}$ \\
Sensitive & $21 / 3$ & 0.01 to $0.2 \mu \mathrm{g} / \mathrm{ml}$ \\
Moderately resistant & $3 / 0$ & 0.2 to $<1 \mu \mathrm{g} / \mathrm{ml}$ \\
Insensitive & $0 / 1$ & $>1 \mu \mathrm{g} / \mathrm{ml}$ \\
\hline
\end{tabular}

${ }^{\mathrm{z}} \mathrm{EC}_{50}=50 \%$ inhibition in the presence of mefenoxam.

Table 4. Morphological characteristics of isolates of Phytophthora nicotianae from sites in the Lower Rio Grande Valley (LRGV) and the Texas Coastal Bend $(\mathrm{TCB})^{\mathrm{y}}$

\begin{tabular}{|c|c|c|c|c|c|c|c|}
\hline Site $(n)^{\mathbf{z}}$ & $\begin{array}{l}\text { Chlamydospore } \\
\text { diameter }(\mu \mathrm{m})\end{array}$ & $\begin{array}{l}\text { Sporangium length } \\
(\mathrm{L})(\boldsymbol{\mu m})\end{array}$ & $\begin{array}{c}\text { Sporangium breadth } \\
(\mathbf{B})(\mu \mathrm{m})\end{array}$ & LB ratio & $\begin{array}{c}\text { Oogonium } \\
\text { diameter }(\mu \mathrm{m})\end{array}$ & $\begin{array}{c}\text { Oospore } \\
\text { diameter }(\mu \mathrm{m})\end{array}$ & $\begin{array}{c}\text { Antheridium } \\
\text { diameter }(\mu \mathbf{m})\end{array}$ \\
\hline $\begin{array}{l}\text { LRGV } \\
\text { (29) }\end{array}$ & $36.5 \pm 0.38 \mathrm{a}$ & $42.28 \pm 0.42 \mathrm{a}$ & $36.4 \pm 0.3 \mathrm{a}$ & $1.32 \pm 0.01$ & $24.9 \pm 0.16$ & $20.3 \pm 0.18$ & $11.4 \pm 0.14$ \\
\hline $\begin{array}{r}\mathrm{TCB} \\
(5)\end{array}$ & $28.1 \pm 0.63 b$ & $38.4 \pm 0.81 b$ & $29.1 \pm 0.58 b$ & $1.30 \pm 0.01$ & $24.5 \pm 0.56$ & $20.3 \pm 0.42$ & $12.2 \pm 0.46$ \\
\hline$F$ value & 15.08 & 36.36 & 40.17 & $\ldots$ & 1.55 & 0.1 & 3.73 \\
\hline$P$ value & 0.0001 & 0.0001 & 0.0001 & $\ldots$ & 0.21 & 0.9 & 0.07 \\
\hline
\end{tabular}

${ }^{y}$ Means followed by different letters are significant at $P<0.05$.

${ }^{\mathrm{z}}$ Site (number of isolates). 
reveal whether foot rot incidence is reduced in new orchards planted with certified materials.

This study showed that the pathogen associated with this disease in Texas is $P$. nicotianae, because it has been the only Phytophthora sp. isolated from citrus soils in this work and in previous studies (Kunta et al. 2007; Timmer 1973). P. nicotianae is known to have a higher optimum temperature for growth, which may provide an advantage over other Phytophthora spp. that cause diseases on citrus and other subtropical crops (Panabieres et al. 2016). The predominance of $P$. nicotianae in Texas soils could be due to the high temperatures reached during the summer months. However, in other regions with warmer climates such as India or Florida, foot rot and root rot infections are caused by $P$. nicotianae and $P$. palmivora (Graham et al. 1998; Sonavane and Venkataravanappa 2017). In Mediterranean climates such as Spain and the Western Cape region of South Africa, $P$. citrophthora is the most prevalent species and $P$. nicotianae populations are less abundant (Alvarez et al. 2008; Meitz-Hopkins et al. 2014). In other regions, seasonal fluctuations affect the ratio between Phytophthora spp. present in the same location. In California, root rot is caused by $P$. nicotianae during warmer times of the year, whereas $P$. citrophthora is present year-round (Hao et al. 2018). Although P. citrophthora was detected by PCR in Texas soils in 2016 (RoyChowdhury et al. 2016), this species was not detected in our surveys. If $P$. citrophthora is present, its abundance is below the detection limit of our culturing assay and may not have an impact in the development of foot rot of citrus in the state.

Characterization of $P$. nicotianae isolates collected from the LRGV and the TCB showed great diversity in chlamydospore and sporangium size and fungicide sensitivity, as well as virulence and pathogenicity to citrus and noncitrus hosts. The finding that these propagules were larger in commercial orchards in the LRGV compared with residential areas in the TCB may imply some adaptation to the environment such as different soil conditions and management practices. Flood irrigation of commercial orchards in Texas may produce anaerobic conditions alternating with very dry soil conditions (Davidson and Janssens 2006). Although a trade-off between size and spore number is expected, larger chlamydospores may be more suited to withstand those extreme environments because larger size may increase spore viability (Mariette et al. 2018).
P. nicotianae has a wide host range (Erwin and Ribeiro 1996). However, in the present study, we have shown some degree of host specificity, because one isolate was nonpathogenic to any of the noncitrus hosts tested and others showed pathogenicity to some hosts but not others. We did not observe strong virulence on bean seedlings, although we were able to recover the pathogen from stem tissues. This is in accordance with other studies where $P$. nicotianae isolates were not pathogenic to snap bean seedlings and weakly virulent on pods (Olson et al. 2016). Sour orange seedlings showed tolerance to Phytophthora sp. because none of the isolates killed the seedlings, although they were able to colonize the roots. Continuous use of predominantly sour orange rootstock in LRGV is justified due to its desirable characteristics of tolerance to the pathogen and good performance in calcareous soils with poor drainage and salinity issues (Roose 2014).

Mefenoxam-based fungicides are widely used to control oomycete pathogens. Their extensive use in agriculture has led to the emergence of insensitive pathogen populations. In open-field nurseries and greenhouses, mefenoxam-resistant $P$. nicotianae isolates have been detected in Florida, North Carolina, and Virginia (Hu et al. 2008; Hwang and Benson 2005; Timmer et al. 1998). Although mefenoxam-resistant isolates were not found in commercial orchards of LRGV, some isolates displayed reduced sensitivity, which may indicate a transitioning stage for resistance development (Venkataramana et al. 2010). Because mefenoxam-insensitive isolates can be as aggressive as sensitive isolates with or without mefenoxam selection pressure (Café-Filho and Ristaino 2008; Chapara et al. 2011; Hu et al. 2008; Taylor et al. 2006; Timmer et al. 1998), a survey for resistance in citrus orchards with known history of mefenoxam use would be beneficial. Nonetheless, the absence of resistant isolates from the sampled LRGV orchards indicates that mefenoxam can still be an effective control for Phytophthora diseases in the area and that alternating fungicides such as oxathiapiprolin, fosetyl-Al, and phosphites, among others, as a resistance management strategy is required.

As management practices begin to change in the LRGV to address water shortages and threatening diseases such as huanglongbing, the study of Phytophthora diseases will also need to continue. New highdensity plantings, implementation of raised beds and ground covers, and the increased use of water-saving irrigation methods (drip and

Table 6. Virulence and pathogenicity of Phytophthora nicotianae isolates and the tissues of pathogen recovery in citrus and noncitrus hosts ${ }^{\mathrm{y}}$

\begin{tabular}{cllll}
\hline Isolate ID & Sour orange & \multicolumn{1}{c}{ Lupinus } & \multicolumn{1}{c}{ Tomato } & \multicolumn{1}{c}{ Squash } \\
\hline LRGV & & & & Bean \\
PhC65 & Negative & Stem, root, leaf+++ & Stem, root, leaf+++ & Root, stem+++ \\
PhH66 & Negative & Stem, root, leaf+++ & Stem, root, leaf+++ & Root, stem++ \\
PhLF2 & Root+ & Stem, root, leaf+++ & Negative & Stem, root++ \\
PhLF25 & Root+ & Stem, root, leaf+++ & Root, stem+++ & Root, stem++ \\
PhLF60 & Negative & Na & Stem, root++ & Negative \\
PhLF75 & Root+ & Stem, root, leaf+++ & Negative & Root, stem+ \\
PhSB14 & Na & Stem, root, leaf+++ & Stem, root, leaf+++ & Root, stem+++ \\
PhA21 & Na & Stem, root, leaf+++ & Stem, root+++ & Root, stem+++ \\
PhD4 & Root+ & Stem, root, leaf+++ & Stem+++ & Stem, root+ \\
PhD6 & Root+ & Root+++ & Stem, root+++ & Stem, root+ \\
PhE32 & Root+ & Negative & Negative & Negative \\
PhMC28 & Root+ & Stem, root, leaf+++ & Stem, root, leaf+++ & Root, stem+ \\
PhMC56 & Root+ & Stem, root, leaf+++ & Stem, root+++ & Negative \\
PhMC72 & Negative & Stem, root, leaf+++ & Stem, root, leaf+++ & Root, stem++ \\
PhMI81 & Root+ & Stem, root, leaf+++ & Na & Root, stem++ \\
PhSJ23 & Root+ & Stem, root, leaf +++ & Stem, root+++ & Root, stem+++ \\
PhW13 & Na & Stem, root, leaf+++ & Stem, root++ & Root, stem++ \\
TCB & & & & Negative \\
PhCC63 & Na & Stem, root+ & Stem+ & Nega \\
PhO44 & Na & Stem, root, leaf+++ & Stem, root, leaf+++ & Negative \\
PhRP24 & Root+ & Root, stem++ & Root, stem, leaf+ & Stem, root+ \\
\hline
\end{tabular}

y Virulence was based on percent mortality and percent of plant segments from which $P$. nicotianae was recovered. Isolates were rated as $+++=$ highly virulent, $++=$ moderately virulent, or $+=$ weakly virulent; negative means nonpathogenic and $\mathrm{Na}=$ not assessed.

${ }^{\mathrm{z}}$ Regions in Texas: LRGV = Lower Rio Grande Valley and TCB $=$ Texas Coastal Bend 
microsprinkler) will likely affect the incidence and severity of Phytophthora diseases. Therefore, further studies are required to evaluate the effect of these new orchard planting strategies.

\section{Acknowledgments}

We thank J. L. Hernandez-Mendoza (Centro de Biotecnologia Genomica, IPN-Reynosa, Mexico) for kindly providing known A1 and A2 P. capsici isolates; R. Bedre and K. K. Mandadi (Texas A\&M AgriLife Research and Extension Center, Weslaco) for helping use the in-house developed Python script to generate the ITS consensus sequences; and the Citrus Center staff C. Barbola, J. M. Hearn, R. Saldaña, and M. Garcia for their assistance with data and sample collection.

\section{Literature Cited}

Alvarez, L. A., Vincent, A., De la Roca, E., Bascón, J., Abad-Campos, P., Armengol, J., and García-Jiménez, J. 2008. Branch cankers on citrus trees in Spain caused by Phytophthora citrophthora. Plant Pathol. 57:84-91.

Blaker, N. S., and MacDonald, J. D. 1986. The role of salinity in the development of Phytophthora root rot of citrus. Phytopathology 76:970-975.

Café-Filho, A. C., and Ristaino, J. B. 2008. Fitness of isolates of Phytophthora capsici resistant to mefenoxam from squash and pepper fields in North Carolina. Plant Dis. 92:1439-1443.

Chapara, V., Taylor, R. J., Pasche, J. S., and Gudmestad, N. 2011. Competitive parasitic fitness of mefenoxam-sensitive and -resistant isolates of Phytophthora erythroseptica under fungicide selection pressure. Plant Dis. 95:691-696.

Cooke, D. E., Drenth, A., Duncan, J. M., Wagels, G., and Brasier, C. M. 2000. A molecular phylogeny of Phytophthora and related oomycetes. Fungal Genet. Biol. 30:17-32.

Da Graça, J. V., and Van Ness, M. E. 2019. The Texas certified virus-free budwood program-20 years on. (Abstr.) J. Citrus Pathol. 6:9-10. https://escholarship.org/uc/iocv_journalcitruspathology/6/1

Davidson, E. A., and Janssens, I. A. 2006. Temperature sensitivity of soil carbon decomposition and feedbacks to climate change. Nature 440:165-173.

Dirac, M. F., Menge, J. A., and Madore, M. A. 2003. Comparison of seasonal infection of citrus roots by Phytophthora citrophthora and $P$. nicotianae var. parasitica. Plant Dis. 87:493-501.

Erwin, D. C., and Ribeiro, O. K. 1996. Phytophthora Diseases Worldwide. American Phytopathological Society, St. Paul, MN, U.S.A.

Ferguson, A. J., and Jeffers, S. N. 1999. Detecting multiple species of Phytophthora in container mixes from ornamental crop nurseries. Plant Dis. 83: 1129-1136.

Finney, D. J. 1962. Probit Analysis. Cambridge University Press, London, U.K

Förster, H., Hao, W., and Adaskaveg, J. 2016. Reduced sensitivity to potassium phosphite in Phytophthora species and its implication for the management of Phytophthora brown rot of citrus. (Abstr.) Phytopathology 106:S4.198.

Furr, J. R., and Carpenter, J. B. 1961. Program for breeding citrus rootstocks tolerant to Phytophthora root rot. Pages 18-23 in: Proc. Fla. Stn. Hortic.

Graham, J., and Feichtenberger, E. 2015. Citrus Phytophthora diseases: Management challenges and successes. J. Citrus Pathol. https://escholarship.org/uc/ item/3db485rh

Graham, J. H., and Menge, J. A. 1999. Root diseases. Pages 128-131 in: Citrus Health Management. L. W. Timmer and L. W. Duncan, eds. American Phytopathological Society, St. Paul, MN, U.S.A.

Graham, J. H., Timmer, L. W., and Dewdney, M. M. 2014. Florida Citrus Pest Management Guide: Phytophthora foot rot and root rot. Univ. Fla. IFAS Ext.

Graham, J. H., Timmer, L. W., Drouillard, D. L., and Peever, T. L. 1998. Characterization of Phytophthora spp. causing outbreaks of citrus brown rot in Florida. Phytopathology 88:724-729.

Hao, W., Gray, M. A., Förster, H., and Adaskaveg, J. E. 2019. Evaluation of new oomycota fungicides for management of Phytophthora root rot of citrus in California. Plant Dis. 103:619-628.

Hao, W., Miles, T. D., Martin, F. N., Browne, G. T., Förster, H., and Adaskaveg, J. E. 2018. Temporal occurrence and niche preferences of Phytophthora spp. causing brown rot of citrus in the Central Valley of California. Phytopathology 108:384-391.

Hu, J. H., Hong, C. X., Stromberg, E. L., and Moorman, G. W. 2008. Mefenoxam sensitivity and fitness analysis of Phytophthora nicotianae isolates from nurseries in Virginia, USA. Plant Pathol. 57:728-736.

Hwang, J., and Benson, D. M. 2005. Identification, mefenoxam sensitivity, and compatibility type of Phytophthora spp. attacking floriculture crops in North Carolina. Plant Dis. 89:185-190.

Jeffers, S. N. 2006. Identifying species of Phytophthora. Department of Entomology, Clemson University, Clemson, SC, U.S.A. https://www.fs.fed.us/ foresthealth/fhm/sp/sod/misc/culturing_species_phytophthora.pdf

Judelson, H. S., and Blanco, F. A. 2005. The spores of Phytophthora: Weapons of the plant destroyer. Nat. Rev. Microbiol. 3:47-58.
Kunta, M., Hongqin, M., and Skaria, M. 2007. Molecular distinction of citrus Phytophthora isolates in the Lower Rio Grande Valley of Texas. Subtrop. Plant Sci. 59:1-5.

Mariette, N., Kröner, A., Mabon, R., Montarry, J., Marquer, B., Corbière, R., Androdias, A., and Andrivon, D. 2018. A trade-off between sporangia size and number exists in the potato late blight pathogen Phytophthora infestans, and is not altered by biotic and abiotic factors. Front. Plant Sci. 9:1841.

Martin, F. N., Tooley, P. W., and Blomquist, C. 2004. Molecular detection of Phytophthora ramorum, the causal agent of sudden oak death in California, and two additional species commonly recovered from diseased plant material. Phytopathology 94:621-631.

Matheron, M. E., and Matejka, J. C. 1990. Differential virulence of Phytophthora parasitica recovered from citrus and other plants to rough lemon and tomato. Plant Dis. 74:138-140.

McKinney, H. H. 1923. Influence of soil, temperature, and moisture on infection of wheat seedlings by Helminthosporium sativum. J. Agric. Res. 26:195-217.

Meitz-Hopkins, J. C., Pretorius, M. C., Spies, C. F. J., Huisman, L., Botha, W. J., Langenhoven, S. D., and McLeod, A. 2014. Phytophthora species distribution in South African citrus production regions. Eur. J. Plant Pathol. 138:733-749.

Menge, J. A., Johnson, E. L. V., Pond, E., Ferrin, D., Liu, H., Lutz, A., Strother, M., Bartnicki, D., Afek, U., and Sjoerdsma, J. 1988. Distribution and frequency of Phytophthora parasitica and Phytophthora citrophthora associated with root rot of citrus in California. (Abstr.) Phytopathology 78:1576.

Mounde, L. G., Ateka, E. M., Kihurani, A. W., Wasilwa, L., and Thuranira, E. G. 2009. Occurrence and distribution of citrus gummosis (Phytophthora spp.) in Kenya. Afr. J. Hortic. Sci. 2:56-68.

Olson, J. D., Damicone, J. P., and Kahn, B. A. 2016. Identification and characterization of isolates of Pythium and Phytophthora spp. from snap beans with cottony leak. Plant Dis. 100:1446-1453.

Panabieres, F., Ali, G. S., Allagui, M. B., Dalio, R. J. D., Gudmestad, N. C., Kuhn, M.-L., Guha Roy, S., Schena, L., and Zampounis, A. 2016. Phytophthora nicotianae diseases worldwide: New knowledge of a long-recognised pathogen. Phytopathol. Mediterr. 55:20-40.

Roose, M. L. 2014. Rootstocks. Pages 95-105 in: Citrus Production Manual. L. Ferguson and E. Grafton-Cardwell, eds. University of California Agriculture and Natural Resources, Richmond, CA.

RoyChowdhury, M., Saini, M., Driver, T., and Minton, B. 2016. Distribution of Phytophthora spp. in Southern Texas citrus grove soils. Plant Health Prog. 17: 182-183.

Sandler, H. A., Timmer, L. W., Graham, J. H., and Zitko, S. E. 1989. Effect of fungicide applications on populations of Phytophthora parasitica and on feeder root densities and fruit yield of citrus trees. Plant Dis. 73:902-906.

Sonavane, P., and Venkataravanappa, V. 2017. Status of Phytophthora and Huanglongbing diseases of citrus causing decline in Coorg mandarin in India. J. Agric. Sci. Technol. B 7:248-263.

Taylor, R. J., Pasche, J. S., and Gudmestad, N. C. 2006. Biological significance of mefenoxam resistance in Phytophthora erythroseptica and its implications for the management of pink rot of potato. Plant Dis. 90:927-934.

Timmer, L. W. 1972. Management of soil-borne diseases of citrus in the Lower Rio Grande Valley. J. Rio Grande Val. Hortic. Soc. 26:28-32.

Timmer, L. W. 1973. Characteristics of Phytophthora isolates from Texas citrus orchards. J. Rio Grande Val. Hortic. Soc. 27:44-48.

Timmer, L. W., Garnsey, S. M., and Graham, J. H., eds. 2000. Compendium of Citrus Diseases, 2nd ed. American Phytopathological Society, St. Paul, MN, U.S.A.

Timmer, L. W., Graham, J. H., and Zitko, S. E. 1998. Metalaxyl-resistant isolates of Phytophthora nicotianae: Occurrence, sensitivity, and competitive parasitic ability on citrus. Plant Dis. 82:254-261.

Timmer, L. W., Sandler, H. A., Graham, J. H., and Zitko, S. E. 1988. Sampling citrus orchards in Florida to estimate populations of Phytophthora parasitica. Phytopathology 78:940-944.

Venkataramana, C., Taylor, R. J., Pasche, J. S., and Gudmestad, N. C. 2010. Prevalence of mefenoxam resistance among Phytophthora erythroseptica Pethybridge isolates in Minnesota and North Dakota. Am. J. Potato Res. 87: 521-530.

White, T. J., Bruns, T., Lee, S., and Taylor, J. 1990. Amplification and direct sequencing of fungal ribosomal RNA genes for phylogenetics. Pages 315-322 in: PCR Protocols: A Guide to Methods and Applications. M. A. Innis, D. H Gelfand, J. J. Sninsky, and T. J. White, eds. Academic Press, San Diego, CA, U.S.A.

Wiedenfeld, B. 2008. Effects of irrigation water salinity and electrostatic water treatment for sugarcane production. Agric. Water Manage. 95:85-88.

Zitko, S. E., and Timmer, L. W. 1994. Competitive parasitic abilities of Phytophthora parasitica and P. palmivora on fibrous roots of citrus. Phytopathology 84:1000-1004.

Zitko, S. E., Timmer, L. W., and Sandler, H. A. 1991. Isolation of Phytophthora palmivora pathogenic to citrus in Florida. Plant Dis. 75:532-535. 